\title{
OPPORTUNITIES OF JOB SEARCH THROUGH SOCIAL MEDIA PLATFORMS AND ITS DEVELOPMENT IN LITHUANIA
}

\author{
Ligita GASPARÉNIENE ${ }^{1 *}$, Snieguolè MATULIENE ${ }^{2}$, Eigirdas ŽEMAITIS ${ }^{3}$ \\ ${ }^{1,2}$ Public Safety Academy, Mykolas Romeris University, Vilnius, Lithuania \\ ${ }^{3}$ Department of Business Technologies and Entrepreneurship, Business Management Faculty, \\ Vilnius Gediminas Technical University, Vilnius, Lithuania
}

Received 13 August 2019; accepted 18 January 2021

\begin{abstract}
On average, everyone has 8.6 accounts on social media platforms. In today's world, social media platforms control a large part of life, one of which is job search. Job searches through social media platforms are already completing the elimination of older traditional job search methods, and the social network LinkedIn, which has become an interactive resume, is slowly outpacing resumes and cover letters in terms of the ability to share recommendations and various expertise. Employers are increasingly posting open job positions on social media platforms, making job postings simple and easily accessible to all users of social media platforms. The main goal of the presented paper is to introduce the recommendations for developing the process of job search through social media platforms using quantitative analysis. This article highlights the concept and peculiarities of social media platforms, advantaged and disadvantages of job search through SMP. The factors influencing job search through social media platforms were presented and analyzed according to the survey, steps for the further development were presented as well. Recommendation to improve the process of job search were provided after theoretical, methodological and empirical part.

The results of the research will help to define the main advantages and disadvantages of job search through SMP from general population of Lithuania, also main concerns regarding its usage were determined. It is faster and easier to find the job through SMP, although do not like that it is necessary to keep an eye on their profile page in the social media, so privacy concern was defined as the biggest disadvantage. The article used the following methods: scientific literature review, quantative analysis (survey).
\end{abstract}

Keywords: job search, social media platforms, LinkedIn, Facebook, Lithuania.

JEL Classification: J11, O15.

\section{Introduction}

Unemployment is one of the main macroeconomic problems, and its level is often a measure of the success of a country's macroeconomic policies (Senjur, 1999). Unemployment causes economic and political problems. The country's actual gross domestic product (GDP) is below potential, i.e. the one that can be generated by the employment of all employable people, making unemployment an undesirable phenomenon in every state (Setnikar-Cankar \& Hrovatin, 2000). The term unemployment can sometimes be tricky and misleading, but it includes people of working age (aged 15 to 74) seeking to enter the labor market (Corporate Finance Institute, n.d.).
Usually unemployment is the problem for elderly people (over 50 years old), but current European situation says that it has become a problem for younger people as well, i.e. those, who have recently graduated from the universities or schools. According to Eurostat, in September 2020, the total seasonally adjusted unemployment rate in European Union was 7.5\%, meanwhile in Lithuania it was $9.8 \%$. In the same period the youth (age under 25 ) unemployment rate was $17.1 \%$, which means that 2.995 million of young persons were unemployed in the EU. In Lithuania the youth (age under 25) unemployment rate was $27.7 \%$.

Young people play a very important role in modern society with their energy and motivation helping them to bring new and creative ideas into the labor market, they

*Corresponding author. E-mail: ligitagaspareniene@mruni.eu 
reflect the potential of a particular economy. Therefore, it is definitely important for the economy to give young people more opportunities by creating favorable conditions that will allow them to develop their talents and participate more actively in the labor market. The participation of young people in the labor market has an important impact on the overall economic and social development of the country, as well as on future sustainability (Bisello \& Mascherini, 2017). In 2020, as many as $73 \%$ people aged 18-34 found their last job position on the social media platform. Social network users check social and professional networks on a daily basis, and jobseekers highly value social and professional networks as promising search channels.

Nowadays social media play important role not only for the communication with friends or family, but for the job search as well. In 2020, the average time spent on social media per day is 2 hours 24 minutes globally for users aged 16 to 64 on any device. Social media monitoring service Reppler made a study, which showed that about $90 \%$ of HRs have checked a potential candidate's profile on one of the social media platforms as part of the screening process. Corporate culture in the organisations has developed as well, and now recruiters would like to see not only hard (such as their actual knowledge and competency in the needed area of work) skills of the potential employees, but also their soft skills (such attitude, personality, abilities, honesty) and their possibility "to fit" into the company (Laker \& Powell, 2011). Such skills can be found out by reviewing social media of the potential candidate - what they post, how they communicate on the Internet, etc. Miller et al. (2016) also stated that SMP (Social Media Platforms) can be considered not only as the place where people share their happenings in life and communicate with others, but also as one of the largest content databases in history. According to Society of Human Resource Management Survey (2018), 95\% of $541 \mathrm{HR}$ managers and specialists were being asked and answered that they used LinkedIn for candidate's research. Also, $58 \%$ used Facebook for recruiting, and $42 \%$ used Twitter. The fact, that most of the organizations nowadays have the profile of their organization in at least one of the SMP, makes it extremely helpful for job seekers.

Recruitment on social networks has proven to be a sustainable tactic in attracting and hiring top talent. The object of this article is the opportunities of job search through SMP in Lithuania.

The purpose of this article is to introduce the recommendations for developing the process of job search through social media platforms using quantitative analysis. For fulfilment of the defined purpose, the following objectives were raised: 1) To analyze theoretical aspects of opportunities of job search through SMP; 2) To present the methodology of opportunities of job search development in Lithuania; 3) To identify the opportunities of job search development through SMP in Lithuania.

The research methods include scientific literature review and quantative analysis (survey).

\section{Literature review: concept and peculiarities of SMP}

According to Newson et al. (2008), the term social media was first mentioned by Chris Shipley, the founder of the Guidewire Group, a researcher of new technological trends. Internet technologies, which have enabled informative communication, participation and collaboration on the Internet, are currently being described. Social media present ads on the Internet that create simple and easily accessible information for and about people. The purpose of social media is to facilitate communication between individuals and their groups. This term often refers to activities that include new technology, telecommunications, social communication, as well as written structures of speech, visual, and audio information. This interaction and way of presenting information creates not only a variety of new perspectives on communication, but also common meanings between communities and individuals. The opportunities offered by social media are not set against by the business world, either; it's as a way to attract either a consumer, a buyer, a partner. Social networks are a platform that allows users to create personal web pages that can provide information about other users, interact with friends and connect with non-infringing people. According to Papacharissi (2009), social network users do not try to make new friends, but only have to strengthen connections with existing friends and acquaintances as much as possible. Social networks can also be used by users to share personal information, such as hobbies or achievements, as well as photos, thoughts, etc. (Constantinides et al., 2008). In other words, social networks are a space where its users can create their own profile, and thus form a personal network that is connected to other users. Perhaps the most important feature of social networking is that it's like a personal website dedicated only to himself, which is most important to each user there.

Web platforms and social networks took a significant place in human's life. According to Narvey (2009), platforms and networks are identified as "free participation that allows (communities) to get engaged and build genuine relationship[s]" (p. 35). There are various examples of social media platforms sites: Facebook, LinkedIn, Instagram, Twitter, Xing, which are spread internationally. There are also a lot of local websites, which are popular in the country of origin: LinkedIn, Xing and Facebook are the most suitable ones for job search because of the presence of job-posting features.

According to Yokoyama (2016), "social network sites are web-based services that allow users to construct an individual profile to interact with contacts and also enable the visualization of friends' network within the system." (p. 4). These platforms allow users to exchange and share information and build online relationships. Such networks complement the offline reality by integrated in them tools. Besides social, they also provide users with technical infrastructure for better communications: wall 
posts, messages, comments, personal information about a user. Most social platforms are based on user's profile, his interests and connections, but they can be aimed on different goals. Instagram is targeted on sharing audio-visual content, Twitter orients on status updates and LinkedIn and Xing are directed on work-related connections. In the case of Facebook, formal and informal relationships are mixed when a person uses it both for developing professional career and for socializing with friends.

According to Boyd and Ellison (2007), social networking sites that allow individuals to create a public or semi-public profile on a selected social networking platform, allow them to connect with other users who have an account on that platform, and view their profile. Al-Amin et al. (2019) conducted a study to find out how social networking sites work for job seekers in Bangladesh, and to find out how many people are looking for the job they want through social networks such as Facebook and LinkedIn. 200 respondents participated in this study. The results of the study revealed that 92 percent of respondents look for work through social networking sites, of which $84.2 \%$ use Facebook for job searches, and 9.8 percent use LinkedIn platforms. HR managers use platforms as a source of information about workforce, they can compare CV with online profile and online behavior of the job seeker. Managers can also find some mutual connections with the applicant, which allows them to ask for recommendations or opinion about a specific person. Platforms can also help the company to follow mood and behavior of current employees. When company is tightly connected with customer services it is very important to have a great image, since every client can enter the employee's profile and refuse company's services because of inappropriate behavior, which is why HR managers also check employees' posts and photos on the Internet.

According to Zide et al. (2014), LinkedIn is a social media site, which is used mostly for building professional relations. It has started reaching its fame since 2003 and became recognized worldwide by both employers and employees. According to Statista.com, the total number of LinkedIn members was rapidly increasing every year since 2009, and in the end of 2020 the total amount of website members has reached 722 millions of people (see Figure 1). Xing is a European career-oriented social network, which is more oriented on a German market, but is also used in other European countries.

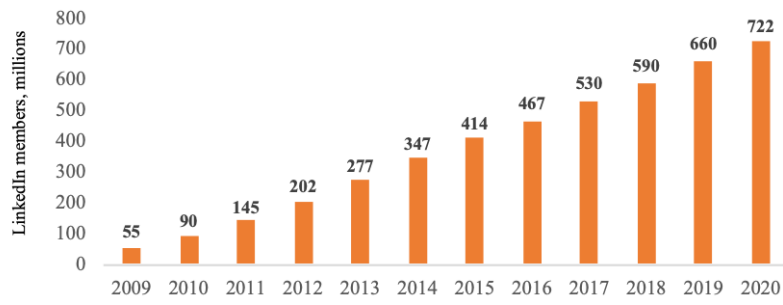

Figure 1. Numbers of worldwide LinkedIn members from 2009 to 2020 (source: created by the author, based on Statista.com, 2020)
Facebook is the most popular social network in the world. According to Statista.com (2020), there are over 2.74 billion monthly active Facebook users for Q3 2020. According to Justice Connect (2014), "it enables the connection of people (users) who have signed up to Facebook with other users, events, businesses, causes, not-for-profits and interest groups." Facebook looks very favorable for companies, which are looking for new employees due to international coverage of completely different groups of people.

Twitter is a handful tool for microblogging, which allows users to post small posts. There are 340 million Twitter users for 2020 , this makes Twitter the $13^{\text {th }}$ most used social media platform. According to Koch et al. (2018), Twitter and Facebook can be used more to showcase the brand of the organization and to generate referrals as well as to post job advertisements, which can be helpful for the job seeker in order to have all the companies he is interested in to be found in one place.

Advantages and disadvantages of job search through SMP. People are getting used to be digitally connected on a daily basis; not only younger population is using social media, but even older people are becoming proficient in it, especially in Europe. This forms a very practical advantage for the platforms - aggregation of employers, job seekers in one place in a huge database. Various technologies allow people to create personalized and detailed searches, which are aimed only on a person's goal.

According to Sayel (2018), one of the first advantage of searching the job using SMP is speed. It takes only a few minutes and minimum efforts to post your CV, using the key words, and detailed search can save much time to find the needed vacancy rather than looking for the needed one among thousands on the newspaper or send the CVs to various organizations one by one. Also, delivery and response time can be immediate.

Similarly to speed, according to Bhupendra and Gairola (2015), broader and deeper pool of vacancies makes SMP a better choice for the job search. International companies and biggest market players are having online presence in all of the SMP, which does not limit the choice for the job seeker to find a desired workplace.

Before SMP became developed among the world, it was almost impossible to find a job in another country; but now SMP and globalization made it much easier for a job seeker to apply the CV or contact the employer in another part of the world as well as for employers to assess a person online without the need to have a physical presence. It can stimulate job seekers to develop their competencies and skills in order to relocate anywhere in case of sufficient knowledge and experience.

Democratized information also forms a great advantage for the SMP. Job seekers can freely find out information about job conditions and reputation of the organization, which also pushes the employer to create better image and strengthen the brand of the company. The democracy in SMP reduces inequality among the participants as recruiter now can consider an ordinary specialist 
altogether with the person, who had connections with the company before. Due to this fact the chances for employer to hire the most suitable worker and the chances for the employee to be hired increase.

There are more possibilities for the job seeker to show and prove its skills (Zide et al. 2014). The person can post the references, digital certificates, which can prove certain skill, e.g. in LinkedIn there is a possibility to verify the achievements, which are shown on a person's profile, former colleagues or clients can leave the references and confirm the skills. This feature is also possible on Xing.

There are also several disadvantages which are formed by using SMP for job search (Verhoeven \& Williams, 2008). Lack of privacy can become one of the major disadvantages of SMP, because recruiters can view the information, which does not belong to professional life of the job seeker and which can negatively influence a person's image and hold to losing the possibility of being hired. The personal account has to be carefully checked and took after, the person should always be connected to social media, which creates and removes the line between personal and professional life.

Despite the fact that most of the international companies are presented in SMP, there still can be local or public ones, where it can be not possible to find a vacancy in the social media or even see their profile. It is improving steadily, but in order to see all the options a person should also double check and combine not only job search through SMP but other ways as well.

Another disadvantage is that the information about job postures can be mixed with other information and news on social media and can be potentially missed. In Facebook and Twitter people are following not only companies but various news portals and friends; this is why the vacancy can be lost among other posts. This possibility can be reduced in LinkedIn and Xing, as it is possible to receive notifications with the new job postures and replies on the job seeker's CV.

The profile in social media does not mean that a real person (recruiter) can be behind it. Hence the possibility of scam can also exist while doing job search through SMP. Scammers can ask for sensitive personal information, which can be used for illegal activity. It is always advised to contact the recruiter from the company by phone or other mean of communication in order to verify the authenticity of the offer and never transmit the personal data (see Table 1).

To conclude, LinkedIn, Facebook, Xing and Twitter are considered the most popular SMP, which are used for job search and their popularity continues to grow, which can be used by the job seekers. Despite of the major disadvantages, authors consider job search mostly through SMP as the most perspective way to find a new employer.

\section{Research methodology}

The goal of the empirical research was to determine the drawbacks of job search through SMP and define the recommendations for successful hire through SMP, have a look on the opinion of working-age Lithuanian population_regarding job search through SMP in order to have a deeper knowledge for improvement and popularization of it. In the empirical part, a quantitative study was performed - an online questionnaire.

Quantitative research is the systematic study of phenomena by collecting quantifiable data and performing statistical, mathematical or computational methods. Quantitative research gathers information from existing and potential customers using sampling methods and by sending online surveys, online surveys, questionnaires, etc., the results obtained can be represented in digital form. According to Kerlinger (1973), survey research is a social scientific research, which focuses on people, their attitudes, opinions and beliefs. The survey researcher is foremost interested in the sociological variables like sex, gender, regions, but even more in what people think and do.

According to Mathiyazhagan and Nandan (2010), there are several phases of the research:

- Primary collection of data;

- Descriptive studies based on the survey;

- The explanation part of the data.

The methodology of the survey consists of several parts (see Figure 2).

For this research online questionnaire was chosen, as this method had replaced mail questionnaires after the development of the Internet. It would be necessary to

Table 1. Advantages and disadvantages of job search through SMP (source: created by the author)

\begin{tabular}{|c|c|c|c|}
\hline \multicolumn{2}{|c|}{ Advantages } & \multicolumn{2}{|c|}{ Disadvantages } \\
\hline Author, year & Theory & Author, year & Theory \\
\hline Zide et al. (2014) & $\begin{array}{l}\text { More possibilities for the job } \\
\text { seeker to show and prove its skills }\end{array}$ & $\begin{array}{l}\text { Verhoeven and Williams } \\
(2008)\end{array}$ & Lack of privacy \\
\hline Sayel (2018) & Speed & $\begin{array}{l}\text { Verhoeven and Williams } \\
(2008)\end{array}$ & $\begin{array}{l}\text { Job postures can be mixed and } \\
\text { missed with other information }\end{array}$ \\
\hline Chen and Haymon (2016) & Democratized information & Chen and Haymon (2016) & $\begin{array}{l}\text { Possibility of scammers behind the } \\
\text { account }\end{array}$ \\
\hline $\begin{array}{l}\text { Bhupendra and Gairola } \\
\text { (2015) }\end{array}$ & $\begin{array}{l}\text { Broader and deeper pool of } \\
\text { vacancies }\end{array}$ & $\begin{array}{l}\text { Verhoeven and Williams } \\
(2008)\end{array}$ & $\begin{array}{l}\text { Some local or public companies may } \\
\text { not have an account in social media }\end{array}$ \\
\hline Chen and Haymon (2016) & Wiping geographical borders & & \\
\hline
\end{tabular}




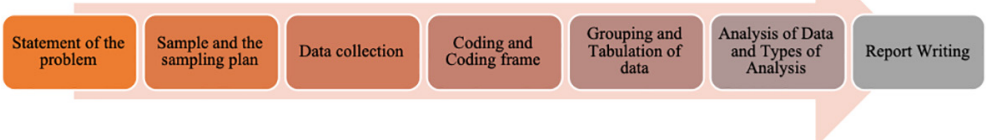

Figure 2. The methodology of the survey (source: created by author)

present main advantages and disdvantages of this method (see Table 2).

Table 2. Advantages and disadvantages online survey questionnaires (source: created by the author, based on Kerlinger (1973))

\begin{tabular}{|l|l|}
\hline \multicolumn{1}{|c|}{ Advantages } & \multicolumn{1}{c|}{ Disadvantages } \\
\hline Cheaper than other methods & $\begin{array}{l}\text { Lower response rate in } \\
\text { comparison with other } \\
\text { methods }\end{array}$ \\
\hline $\begin{array}{l}\text { In case of even national level } \\
\text { survey can be made very fast }\end{array}$ & $\begin{array}{l}\text { Can be used only with online } \\
\text { population }\end{array}$ \\
\hline $\begin{array}{l}\text { Uniformity in responses can } \\
\text { be ensured }\end{array}$ & $\begin{array}{l}\text { Ambiguous replies and } \\
\text { omission of replies to certain } \\
\text { questions can happen. }\end{array}$ \\
\hline Anonymity can be provided & $\begin{array}{l}\text { There is no interviewer to } \\
\text { solve the misunderstandings } \\
\text { in case of any. }\end{array}$ \\
\hline $\begin{array}{l}\text { Automation and real-time } \\
\text { access }\end{array}$ & $\begin{array}{l}\text { Possibility of fraud during the } \\
\text { questionnaire being answered. }\end{array}$ \\
\hline
\end{tabular}

Survey participants' selection criteria. According to Mathers et al. (2009), in order to obtain a random sample, the first step is to define the population, which has to be drawn. In this research it was decided to choose general working population of Lithuania from 18 to 65 years old men and women, which can give comprehensive answers, from which valuable results can be obtained. Mathers et al. (2009) stated that if selections are made by chance only, this is known as simple random sampling. This method has been used in the research, because it would be impossible to keep the national represantatives quotas as gender, age and region due to job search via SMP, and online panels had to be involved. According to Andrews et al. (2003), simple random sampling can be used without keeping the quotas in the questionnaires, which do not necessarily need to be analyzed by using demographics.

In the survey, quotas only on age and current place of living were set up. It was programed in the way, that if the respondent marks that he is $<18$ and $>65$, he would be screened out from the survey. Same situation was with the current place of living: the respondents could choose two options, Lithuania and other country; in case they had pressed "other country", they would be screened out.

Convenience sampling also need to be mentioned because this technique has been used. This sampling is being used when selecting participants since they are easily available. This method is considered to be a favourite student-aiming ad, being it inexpensive and the easiest option to compare with other sampling techniques, though.
It means that researchers can use their friends and family for the survey, which is easier than targeting unknown people (Taherdoost, 2016).

After reaching the target group for this survey (18-65 residents of Lithuania), the incidence rate for the survey became $100 \%$, because even the respondents, who marked that they had never used social media for job search, could finish the survey by exposing the reasons why they had never tried it.

Briefly, these are the necessary criteria for the respondent of the survey:

- 18-65 yeard old,

- Living in Lithuania at the current moment.

The respondents using simple random sampling and convenience sampling were inquired.

Organization of the survey. The survey respondents were asked to fill the questionnaire indirectly by Facebook (simple random sampling) and directly in case of friends and family (convenience sampling). The questionnaire was prepared online in advance, Surveygizmo.com was used as well as for experts' evaluation survey.The website had been chosen because of the possibility to export the data to SPSS and Microsoft Excel. The survey was device agnostic, which made it easier to get more responses from the general population in Lithuania.The survey was carried out during July, 2019 and included 190 respondents of working age living in Lithuania. To estimate the needed sample size, Internet survey system calculator http:// www.surveysystem.com/sscalc.htm_(The Survey System, n.d.) has been used. According to Statistical Yearbook of Lithuania (2018), there are 1.731 .500 people of working age, which means that in order to ensure $5 \%$ error rate, which was estimated by the Internet survey system calculator, 384 respondents need to be asked. The real number of gathered cases is 190, which has raised the error rate till $7 \%$.

\section{The results of the survey for the general population of Lithuania}

The gathered data had been analysed using statistical program SPSS and Microsoft Excel sofware package. For the analysis of the survey results, it has been decided to use $p$ value and mean value.

According to Ferreira and Patina (2015), $p$ value can be defined as a "probability of observing between the given value of the test statistic, or greater, under the null hypothesis". In general, $p$ value defines whether the survey is statistically significant or not. According to Filho et al. 
(2013), $p$ value can be highly significant, marginally significant and not statistically significant, with the cutoffs for these definitions at $\mathrm{p} \leq 0.01, \mathrm{p} \leq 0.05$ and $\mathrm{p}>0.10$.

Mean value defines averages or central tendency; usually it is used in a variety of contexts and it forms the basis of statistics. In case of statistical data, arithmetic mean is being used. To calculate the arithmetic mean of set of data, it is needed to sum all of the data values, after that to divide the result by the number of values (1).

$$
\bar{\chi}=\frac{\sum \chi}{n} .
$$

Cronbach's Alpha for the whole survey had been calculated, and the obtained result showed that Cronbach alpha $=0,6964$, which means that the questionnaire reflects the researched object, as according to Malhotra and Birks (2003), the critical value of the coefficient is 0.6.

The first part of the questionnaire was designed to get general information about the respondents. The goal is to have cross tables in order to realize whether the demographical characteristics can influence job search through SMP.

The first question was dedicated to find out respondents' gender. The results showed, that the ratio among men and women was kept according to national representatives of the country, where $45.3 \%$ were males and $54.7 \%$ were females.

In the second question respondents were asked to specify their age; various age groups from 18-65 were offered, also 66 and more. One person, who had marked " 66 and more option", was screened out from the survey. $45.6 \%$ of the respondents are from 18 to 29 years old, $36.9 \%$ are aged $30-39,13.4 \%$ belong to $40-49$ age group and $3.4 \%$ belong to the age group of 50-65.

The third question was dedicated to find out the country, where the respondents had been currently living. It was made in order to have only people from Lithuania answering the survey. $8,8 \%$ were screened out, because they had marked that they live in another country. $91.2 \%$ answered that they lived in Lithuania and could continue the survey.

In the fourth question it was needed to specify the settlement type of the place of living. $71 \%$ of the respondents marked that they lived in a big city (300 000-1 000000 people), $17 \%$ marked that they lived in a city (100 000300000 people), $2.2 \%$ lived in a large town (20 000100000 people), $6.7 \%$ lived in a town (1000-20 000 people) and $2.2 \%$ marked that they lived in a village (100-1000 people).

In the fifth question it was important to know the level of respondents' education in order to check the connection between the level of education and usage of SMP for job search. $89.6 \%$ of the respondents have higher education, $7.4 \%$ have secondary education, $2.2 \%$ have secondary vocational (professional) education and $0.7 \%$ have primary education.

In the sixth question it was necessary for the respondents to answer the employment status. $49.6 \%$ marked that they are employed by the private company; $17 \%$ marked that they are students; $13.3 \%$ of the respondents are having their own business; $11.1 \%$ are employed by the public company; $5.2 \%$ are not employed, $3 \%$ clicked "Other" (the answers were: freelance, self-employed in a law firm, student and working, professor in a university), $0.7 \%$ marked that they are the retiree.

In the seventh question respondents had to answer whether they have ever used SMP to find a job. As it can be seen from Figure 20, 65.4\% answered positively, while $34.6 \%$ marked "no" and were redirected to the last question, which asked what the reasons for not using SMP for job search were (see Figure 3).

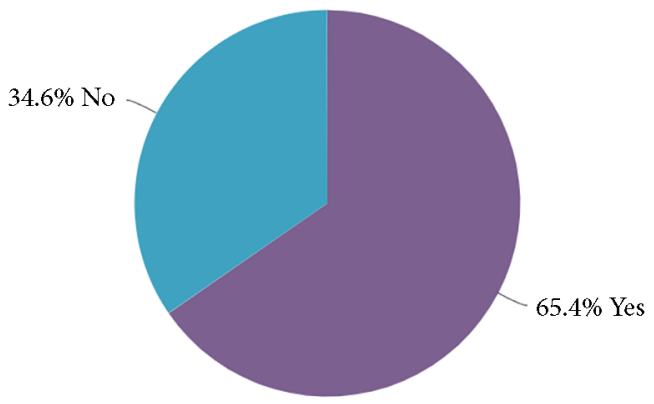

Figure 3. The percentage of users of SMP for job search (source: created by the author, based on the results of the survey)

According to the chart, $41.7 \%$ male and $58.3 \%$ female have used SMP to find a job, while $52.4 \%$ of males and $47.6 \%$ females have never used it before. SMP has been used for job search by $45 \%$ of male respondents aged 18 $29 ; 31.7$ per cent were aged $30-39,18.3 \%$ were female aged $40-49$ and $5 \%$ were aged $50-65.38 .1 \%$ of male respondents $18-29$ years old, $45.2 \%$ of males $30-39$ years of age, $14.3 \%$ females aged $40-49$ and $2.4 \%$ females aged $50-65$ have never used it.

The number of respondents, who have used SMP for job search, living in a big city makes $78,4 \%, 15 \%$ live in a city, $3.3 \%$ live in a town and $1.7 \%$ live in a village. Citizens who have never used it for job search divide into: $73.8 \%$ live in a big city, $19 \%$ live in a city and $7.1 \%$ reside in a town.

SMP for job search was used by $5 \%$ of people with secondary education, $3.3 \%$ with secondary vocational education, $91.7 \%$ with higher education, while $9.5 \%$ of people with secondary and $90.5 \%$ with higher education have never used it. According to the status of respondents, 8.3\% of them have their own business, $61.7 \%$ are employed by a private company, $6.7 \%$ are employees in a public company, $11.7 \%$ of them are students, $5 \%$ are unemployed and $6.7 \%$, who specified "other" have looked for the job using SMP. Meanwhile, $23.8 \%$ of people having their own business, $42.9 \%$ employed by the private company, $14.3 \%$ employed by the public company, $11.9 \%$ of students and $7.1 \%$ of the unemployed have never used SMP for job search.

The second part of the questionnaire was dedicated to the identification of the most popular ways of job search 
in order to compare the opinions of the experts and general population of Lithuania.

In the first question various ways of job search were provided. As it may be seen from the Table 3 , the answers are relevant enough, although respondents' opinions' concordance is weak (Kendall's Wa $=0.432$ ). Factors three, four, five, six and nine gathered high score of mean value: word of mouth 3.5 , online recruitment platforms -4.22 ; professional social media platforms for job search - 3.92; social media platforms for job search - 3.71; recommendations from other people 3.93. The high $p$ values for these factors are emphasizing their significance. The rest of the factors marked by number one, two, seven, eight had weak mean values.

In the third part of the survey respondents had to help to identify advantages and disadvantages of job search through SMP.

In the first question they were offered to evaluate the statements, which compare job search through SMP with traditional ways of job search.

As it may be seen from the Table 4, the answers are relevant, but respondents' opinions' concordance is weak
(Kendall's Wa $=0.490$ ). All of the factors from one to five and factor number eight gathered high score of mean value, as people marked that it is: faster - 3.89; easier 3.98; more efficient - 3.69. It also allows to know more about the employer -3.69 ; opens a wider choice of professions - 3.69; makes it possible to find a job even outside Lithuania -4.01 . The high $p$ values for these factors are emphasizing their significance.

In the second question respondents were asked to evaluate the statements regarding the main drawbacks of job search through social media platforms.

As it may be seen from the Table 5, the answers are relevant, but respondents' opinions' concordance is weak (Kendall's Wa $=0.468$ ). Factors one, two, three and six gathered high score of mean value: watching out carefully for the account -4.19 ; not all employers use social media - 3.67, privacy can be harmed - 3.64, higher possibility of scam -3.55 . The high $p$ values for these factors are emphasizing their significance. The rest of the factors marked by number four, five had both weak mean values, while $p$ values are statistically

Table 3. The most popular ways of job search (source: created by the author, based on the results of the survey)

\begin{tabular}{|c|l|c|c|c|}
\hline \multirow{2}{*}{ No } & \multicolumn{1}{|c|}{ Factor } & \multicolumn{3}{|c|}{ Kendall's $W^{\mathrm{a}}=0.432$} \\
\cline { 2 - 5 } & & \multicolumn{1}{|c|}{ Mean rank } & Mean value & P value \\
\hline 1. & You use newspapers, magazines, paper-based advertisements to find a job. & 2.57 & 1.76 & 0.00 \\
\hline 2. & You use labour exchange office to find a job. & 2.86 & 2 & 0.00 \\
\hline 3. & You rely on word of mouth to find a new job. & 5.43 & 3.5 & 0.00 \\
\hline 4. & You use online recruitment platforms (cvonline lt, cvbankas lt, etc ). & 6.95 & 4.22 & 0.00 \\
\hline 5. & You use professional social media platforms for job search (LinkedIn com, Xing com, & 6.53 & 3.92 & 0.00 \\
\hline 6. & You use social media platforms for job search (Facebook com, twiterr com, etc.) & 6.06 & 3.71 & 0.00 \\
\hline 7. & You try to find a new job in your current company internally. & 4.10 & 2.8 & 0.30 \\
\hline 8. & You use job search agencies to find a job & 4.10 & 2.66 & 0.08 \\
\hline 9. & You use recommendations from your colleagues, friends, family. & 6.40 & 3.93 & 0.08 \\
\hline
\end{tabular}

Table 4. Comparison of SMP with traditional ways of job search (source: created by the author, based on the results of the survey)

\begin{tabular}{|c|c|c|c|c|}
\hline \multirow{2}{*}{ No } & \multirow{2}{*}{ Factor } & \multicolumn{3}{|c|}{ Kendall's $\mathrm{W}^{\mathrm{a}}=0.490$} \\
\hline & & Mean rank & Mean value & $P$ value \\
\hline 1. & $\begin{array}{l}\text { Finding a job through social media platforms (professional and non-professional) is } \\
\text { faster. }\end{array}$ & 4.88 & 3.89 & 0.00 \\
\hline 2. & $\begin{array}{l}\text { Finding a job through social media platforms (professional and non-professional) is } \\
\text { easier. }\end{array}$ & 5.14 & 3.98 & 0.00 \\
\hline 3. & $\begin{array}{l}\text { Finding a job through social media platforms (professional and non-professional) is } \\
\text { more efficient. }\end{array}$ & 4.36 & 3.69 & 0.00 \\
\hline 4. & $\begin{array}{l}\text { Finding a job through social media platforms (professional and non-professional) allows } \\
\text { to know more about the employer. }\end{array}$ & 4.46 & 3.69 & 0.00 \\
\hline 5. & $\begin{array}{l}\text { Finding a job through social media platforms (professional and non-professional) opens } \\
\text { a wider choice of professions. }\end{array}$ & 4.30 & 3.69 & 0.00 \\
\hline 6. & $\begin{array}{l}\text { Finding a job through social media platforms (professional and non-professional) allows } \\
\text { to know company's culture and values. }\end{array}$ & 3.78 & 3.37 & 0.00 \\
\hline 7. & $\begin{array}{l}\text { Finding a job through social media platforms makes the process more responsive } \\
\text { (employers response more often). }\end{array}$ & 3.71 & 3.42 & 0.00 \\
\hline 8. & You can find a job even outside Lithuania. & 5.37 & 4.01 & 0.00 \\
\hline
\end{tabular}


Table 5. The main drawback of job search through SMP (source: created by the author, based on the results of the survey)

\begin{tabular}{|c|l|c|c|c|}
\hline \multirow{2}{*}{ No } & \multicolumn{1}{|c|}{ Factor } & \multicolumn{2}{|c|}{ Kendall's $\mathrm{W}^{\mathrm{a}}=0.468$} \\
\cline { 2 - 5 } & & \multicolumn{1}{|c|}{ Mean rank } & Mean value & P value \\
\hline 1. & $\begin{array}{l}\text { Your privacy can be harmed (you do not want the potential employer to view } \\
\text { your personal life). }\end{array}$ & 3.49 & 3.64 & 0.00 \\
\hline 2. & $\begin{array}{l}\text { You have to carefully watch out for your account (to attach the employer you } \\
\text { have to post only "appropriate" information and pictures). }\end{array}$ & 4.19 & 4.01 \\
\hline 3. & $\begin{array}{l}\text { Not all employers use social media, which means, that you have to send your } \\
\text { CV by other ways. }\end{array}$ & 3.63 & 3.67 & 0.00 \\
\hline 4. & $\begin{array}{l}\text { You always have to be connected to your social media (you need to check them } \\
\text { all the time in order to find a reply or new position). }\end{array}$ & 3.19 & 3.38 & 0.01 \\
\hline 5. & $\begin{array}{l}\text { Mixed information (information about job posts is mixed with information, } \\
\text { which is not related to that). }\end{array}$ & 3.03 & 3.33 & 0.02 \\
\hline 6 & $\begin{array}{l}\text { There is a bigger possibility of scam (everybody can create an account in social } \\
\text { media, which mean you can become a victim of a scammer). }\end{array}$ & 3.47 & 3.55 & 0.00 \\
\hline
\end{tabular}

significant.

In the third question respondents specified, which of the SMP they have ever used to find a job. $78.7 \%$ have used LinkedIn, 67.2\% have used Facebook, 9.8\% have used Xing, 9.8\% marked "Other", but all the options provided can not be considered as SMP, as there are online platforms for recruitment and messengers. 3.3\% marked Twitter (see Figure 4).

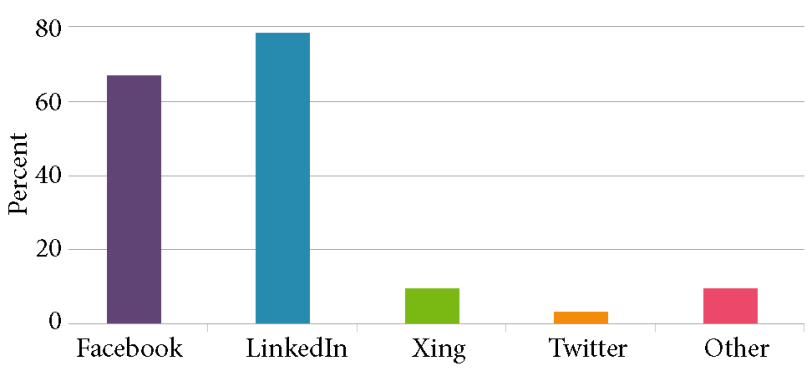

Figure 4. Platforms, which have been used by respondents for job search (percentage) (source: created by the author, based on the results of the survey)

In the fourth question, respondents were offered to specify whether they have ever had successful experience of job search through SMP. 55.7\% marked that they had had successful experience, $44.3 \%$ marked "no" as an answer.

In the fifth question the opinion of the respondents regarding whether SMP can replace other ways of job search was asked. 47.5\% marked "yes" as an answer, $45.9 \%$ answered negatively, 6.6\% marked "other" and the options provided were "very soon can replace", "it will replace, but it is a great additional platform" and others specify the same.

According to the chart, $51.7 \%$ male and $48.3 \%$ female think that SMP can replace other ways of job search, $29.6 \%$ male and $70.4 \%$ female disagree with that, $50 \%$ of male and female answered "other". $44.8 \%$ of people aged $18-29,41.4 \%$ aged $30-39,6.9 \%$ aged $40-49,6.9 \%$ aged 50-65 agreed that SMP can replace other ways of job search, while $48.1 \%$ of $18-29$ y.o., $22.2 \%$ of $30-39$ y.o., $25.9 \%$ aged $40-49$ and $3.7 \%$ aged $50-65$ answered negatively. $82.8 \%$ of respondents living in a big city, $10.3 \%$ of those living in a city, $6.9 \%$ who rside in a town consider that SMP can replace other ways of job search. As compared, $74.1 \%$ of those living in a big city, $18.5 \%$ of a city, $3.7 \%$ of a large town and 3,7\% from village do not think it can be a replacement. Other survey responses include: $100 \%$ of people with higher education think that SMP can replace other ways of job search, while $11.1 \%$ with secondary education, $7.4 \%$ with secondary vocational and $81.5 \%$ with higher education do not think the same. According to the status of respondents who think that SMP can replace all other ways of job search, 3.4\% have their own business, $58.6 \%$ are employed by a private company, $6.9 \%$ are employed by a public company. $17.2 \%$ of them are students, $6.9 \%$ are unemployed or employed by a public company and $6.9 \%$ stated "other". $11.1 \%$ of people having their own business, $66.7 \%$ employed by a private company, $3.7 \%$ employed by a public company, $7.4 \%$ of students, $3.7 \%$ of the unemployed and those $7.4 \%$, who specify "other", do not think it can be a replacement.

In the sixth question, respondents' recommendations for the successful job search through SMP were made.

As it may be seen below, the answers are not relevant, respondents' opinions' concordance is very weak (Kendall's $\mathrm{Wa}=0.010)$. None of the factors got high enough mean values, which means that none of the factors are important enough, but $p$ values are statistically significant.

- Include precise description about your education and work history;

- Present a positive image of yourself;

- Join professionally focused groups and communities and be active in discussions;

- Present all your professional achievements.

In the last question of the survey only the respondents, who marked that they had never used SMP for job search, were addressed. The reasons of non-usage were asked for provision. 
As it may be seen below, the answers (I do not use social media in general (mean value 1.08); I consider social media as my private life (2.90); I find it inconvenient in comparison with other ways of job search (2.92); I do not believe that it is possible to find a job through social media pltaforms (2.38); I prefer traditional ways to find the job (newspapers, magazines, paper-based advertisements, labor exchange office, word of mouth, recruitment agencies, internally in your current organization, recommendations from others (3.29)) are relevant, but respondents' opinions' concordance is weak (Kendall's Wa $=0.234$ ). All of the factors had weak mean values and strong $p$ values, while number five has not got significant $p$ value.

Summing up the results of the survey, the following conclusions can be made:

- All demographical groups of general Lithuanian population are presented in the results.

- Most of the respondents used SMP to find a job.

Online recruitment platforms, professional SMP and recommendations from other people are the most popular ways of job search.

Respondents answered that the main advantage of SMP over other ways of job search is simplicity of usage.

The main drawback of the job search through SMP is constant watching out for the account and posting only "proper" information on the page. It was declared, that not all the employers can use social media as a second drawback.

The most popular platforms for job search through SMP are considered LinkedIn and Facebook.

Most of the respondents also marked, that they had successful experience in job search through SMP and that they think it can replace all other ways of job search.

Respondents couldn't come to any significant recommendation for successful job search through SMP.

Respondents, who marked that they have never searched for a job in SMP, mostly consider social media as their private life, which is why they do not want to use it for job search.

The portrait of the person who does not use SMP for job search has been defined: men and women 30-39 y.o. from cities and towns with secondary education, having their own business or employed by public companies.

The portrait of a person who does not think that SMP can replace all other ways of job search had been defined: female aged 40-49 from cities, large towns and villages with secondary vocational and secondary education, who can possibly have their own business or employed by the private companies.

\section{Conclusions and discussion}

The analysis of scientific literature sources revealed the advantages of job search through SMP, such as greater opportunities for job seekers to show their skills, job search speed, democratized information, large and wide choice of open job positions. However, job search through SMP also has drawbacks such as low privacy, job postings can get lost in other news feeds, not all companies have accounts with SMP, or risk of being scammed.

Based on the results of the survey of 190 Lithuanian residents aged $18-65,65.4 \%$ of respondents used SMP to look for work. Almost half of the respondents (45.6\%) were in the age group of $18-29.78 .7 \%$ of all respondents used LinkedIn, 67.2\% used Facebook, 9.8\% - Xing, and $3.3 \%$ used Twitter. However, only $47.6 \%$ of respondents indicated that SMP can change other ways of looking for work, so it can be stated that nowadays SMP can't replace all other ways of job search due to the fact, that people consider SMP as their personal space, which can't be used for professional life. Also, the concerns regarding incomplete pool coverage of the employers play an important role. Nevertheless, respondents stated that they use SMP in combination with other ways of job search most often, and that it can be replaced by all other ways of recruitment. More than a half of the respondents (55.7\%) stated that they had had successful experience in a job search through SMP, which means that even now there are people who are hired using only SMP.

The obtained data can be used by the organizations in order to see which people can be targeted by SMP; the doubts regarding incomplete pool coverage of the employers can be removed by creating profiles for organisations and using them as the main tool for the recruitment. Further investigation on the topic can be conducted in order to reveal how job seekers assess the employers by their presence in social media, which can help the organizations to build a strong online brand, which will attract the best possible candidates to their vacancies.

Currently, it is impossible to use only SMP for job search in such country like Lithuania, and it is better to combine this method with others. It is important in the case of people, who are aiming for lower or higher (managerial) professions, aged over 30 . In order to attract all types of people for erecruitment through SMP, the companies should move the main focus on SMP like Facebook and LinkedIn.

\section{References}

Andrews, D., Nonnecke, B., \& Preece, J. (2003). Electronic survey methodology: A case study in reaching hard to involve Internet Users. International Journal of Human-Computer Interaction, 16(2), 185-210. https://doi.org/10.1207/S15327590IJHC1602_04

Al-Amin, M., Nafi, S., \& Amin, M. A. (2019). Use of social media for job search and application: a perspective from the job seekers in Bangladesh. Discovery, 55(281).

Bhupendra, S. H., \& Gairola, S. (2015). Importance of social networking sites in e-recruitment. International Journal of Technology Enhancements and Emerging Engineering Research, 3(7), 91-95.

Bisello, M., \& Mascherini, M. (2017). The gender employment gap: costs and policy responses. Intereconomics, 52(1), 24-27. https://doi.org/10.1007/s10272-017-0638-y

Boyd, D. M., \& Ellison, N. B. (2007). Social network sites: Definition, history, and scholarship. Journal of Computer-Mediated Communication, 13(1), 210-230.

https://doi.org/10.1111/j.1083-6101.2007.00393.x 
Chen, C., \& Haymon, M. (2016). Realising the potential of digital job-seeking platforms. Prepared for Brookings Blum Roundtable. https://www.brookings.edu/wp-content/uploads/2016/07/ Global_20160720_Blum_ChenHaymon.pdf

Constantinides, E., Romero, C. L., \& Gómez Boria, M. A. (2008). Social media: a new frontier for retailers? In European Retail Research (pp. 1-28). https://doi.org/10.1007/978-3-83498099-1_1

Corporate Finance Institute (n.d.). What is unemployment? https://corporatefinanceinstitute.com/resources/knowledge/ economics/unemployment/

Eurostat. (n.d.) Unemployment statistics. https://ec.europa.eu/ eurostat/statistics-explained/index.php/Unemployment_statistics

Ferreira, J. C., \& Patina, C. M. (2015). What does the p value really mean? Jornal Brasileiro de Pneumologia, 41(5), 485-485. https://doi.org/10.1590/S1806-37132015000000215

Filho, D. B. F., Paranhos, R., da Rocha, E. C., Batista, M., da Silva, J. A., Santos, M. L. W., \& Marino, J. G. (2013). When is statistical significance not significant? Brazilian Political Science Review, 7(1), 31-55. https://doi.org/10.1590/S1981-38212013000100002

Justice Connect. (2014). Facebook And Your Organization. Legal Information For Community Organisations. https://nfplaw. org.au/sites/default/files/media/Facebook_and_your_organisation_0_0_0.pdf

Kerlinger, F. N. (1973). Foundation of behavioural research (2nd ed.). Holt, Rinehart and Winston.

Koch, T., Gerber, C., \& De Klerk, J. J. (2018). The impact of social media on recruitment: Are you LinkedIn? SA Journal of $\mathrm{Hu}$ man Resource Management/SA Tydskrif vir Menslikehulpbronbestuur, 16(0), a861. https://doi.org/10.4102/sajhrm.v16i0.861

Laker, D. R., \& Powell, J. L. (2011). The differences between hard and soft skills and their relative impact on training transfer. Human Resource Development Quarterly, 22(1), 111-122. https://doi.org/10.1002/hrdq.20063

Malhotra, N. K., \& Birks, D. F. (2003). Marketing research: an applied orientation. Prentice Hall.

Mathers, N., Fox, N., \& Hunn, A. (2009). Surveys and questionnaires (pp. 1-48). In The NIHR Research Design Service for Yorkshire \& the Humber.

Mathiyazhagan, T., \& Nandan, D. (2010). Survey research method. Media Mimansa, (July-September), 34-38.

http://citeseerx.ist.psu.edu/viewdoc/download?doi=10.1.1.46 $4.5585 \&$ rep $=$ rep $1 \&$ type $=$ pdf

Miller, D., Costa, E., Haynes, N., McDonald, T., Nicolescu, R., Sinanan, J., Spyer, J., Venkatraman, S., \& Wang, X. (2016). Why we post. How the world changed social media (pp. 1-288). UCL Press. https://doi.org/10.2307/j.ctt1g69z35
Narvey, J. (2009). Let's get social. BC Business, 37(5), 31-39.

Newson, A., Houghton, D., \& Patten, J. (2008). Blogging and other social media - exploiting the technology and protecting the enterprise. http://books.google.com/books?id=T32mydjv a 0 AC\&printsec $=$ frontcover\&dq=Blogging + and + Other + Soci al+Media\%E2\%80\%93+Exploiting+the+Technology+and+P rotecting+the+Enterprise $\&$ ei $=6 \mathrm{fH} 9 \mathrm{SaqOO} 5 \mathrm{OCygSuiZ36 \textrm {Dw }}$

Papacharissi, Z. (2009). The virtual geographies of social networks: a comparative analysis of Facebook, LinkedIn and ASmallWorld. New Media Society, 11(1-2), 199-220. https://doi.org/10.1177/1461444808099577

Sayel, S. (2018). Impact of online recruitment on recruitment. International Journal of Education and Research, 6(4), 47-52. https://www.ijern.com/journal/2018/April-2018/04.pdf?fbcli d=IwAR0TcmDI7lFYpHeC8SbodAzPo5092MBhmOIz442Aa dy9L5yTEKPnhHfO9q4

Senjur, M. (1999). Makroekonomija majhnega odprtega gospodarstva. Ekonomska fakulteta.

Setnikar-Cankar, S., \& Hrovatin, N. (2000). Temelji ekonomije. Visoka upravna šola.

Society for Human Resource Management (SHRM). (2018). Employee benefits. https://www.shrm.org/hr-today/trendsand-forecasting/research-and-surveys/pages/2018-employeebenefits.aspx

Statista. (n.d.) Numbers of LinkedIn members from 1st quarter to 3rd quarter 2016. https://www.statista.com/statistics/274050/ quarterly-numbers-of-linkedin-members/

Taherdoost, H. (2016). Sampling methods in research methodology; how to choose a sampling technique for research. International Journal of Academic Research in Management, 5(2), 18-27. https://doi.org/10.2139/ssrn.3205035

The Survey System. (n.d.). Sample Size Calculator. http://www.surveysystem.com/sscalc.htm

Verhoeven, H., Williams, S. (2008). Advantages and disadvantages of internet recruitment: A UK study into employers' perceptions. International Review of Business Research Papers, 4(1), 364-373.

http://www.bizresearchpapers.com/Paper-24new.pdf

Yokoyama, M. H. (2016). How social network sites (SNS) have changed the employer - employee relationship and what are the next challenges for human resource (HR). REGE - Revista de Gestão, 23(1), 2-9. https://doi.org/10.1016/j.rege.2015.11.001

Zide, J., Elman, B., \& Shahani-Denning, C. (2014). LinkedIn and recruitment: how profiles differ across occupations. Employee Relations, 36(5), 583-604.

https://doi.org/10.1108/ER-07-2013-0086 